\title{
Foreign Aid Strategies: China Taking Over?
}

\author{
Kristian Kjøllesdal (Corresponding author) \\ Comte Analysebyrå \\ PO box 59 Nydalen, N-0410 Oslo, Norway \\ Tel: 47-915-86-230 E-mail: kristian.ak@gmail.com
}

\author{
Professor Anne Welle-Strand \\ BI Norwegian School of Management \\ Nydalsveien 37, N-0442 Oslo, Norway
}

Tel: 47-464-10-765 E-mail: anne.welle-strand@bi.no

\begin{abstract}
Over the past decade China has emerged as an important source of foreign aid for African countries. Providing aid on terms of its own choosing, China challenges the current foreign aid paradigm in four main ways: The donor-recipient relationship is challenged by a partnership of equals; The modes of provision are challenged by China's focus on aid that is mutually beneficial; The use of conditionalities is challenged by China's insistence on sovereignty and non-interference in domestic affairs; Multilateralism is challenged by China's preference of going the major foreign aid projects alone. This article argues that China's aid programme is not likely to undergo drastic change, and that the effects of China's foreign aid on the traditional donors are already discernible on the African continent. The potency of these challenges might herald that the Chinese approach will provide the frame of reference for foreign aid in the future.
\end{abstract}

Keywords: Economic assistance, Foreign aid, Developing countries, Developed countries, Economic policy, Sino-African relations

\section{Introduction}

Recent observations of international trends in development aid strategies give fair reason to wonder if a Chinese model is substituting the traditional Western strategies. In November 2009, at the fourth meeting of the Forum on China-Africa Cooperation (FOCAC), Premier Wen Jiabao expressed China's intent to deepen its relationship with African countries - a relationship that is fast growing more important for Africa. This relationship, of which Chinese foreign aid is the glue, challenges the very understanding of foreign aid and the development paradigm.

Where previous studies have analysed aspects of Chinese foreign aid provision and its implementation in Africa, these areas of focus have generally not been found combined in the same article. Drawing on earlier contributions, in this article an attempt is made to bridge that gap by establishing a link from Chinese aid organisation, through its implementation in Africa, and to the impact on the very understanding of foreign aid.

Firstly, the Chinese model for economic development reflecting the country's foreign aid history is sketched, with a particular focus on its organisation of grants, technical assistance and concessional lending. Secondly, a comparison of Chinese and traditional donors' aid is made, aiming at highlighting the differences between them. Thirdly, it is analysed how the Chinese model is challenging the frame of reference for foreign aid, before some concluding remarks are made.

\subsection{A Chinese model for economic development}

At the fourth tri-annual summit of the Forum of China-Africa Cooperation in Egypt late 2009, Premier Wen iterated the importance of China's ties with African countries. Over the next three years China will provide $\$ 10$ billion in low-interest loans to African countries, bolster the China-Africa Development Fund by an additional $\$ 1$ billion, as well as cancel debt owed by highly indebted countries with which China has diplomatic relations. These promises are just the most recent examples of how China is 'going it alone'.

In analysing the Chinese approach to foreign aid, three characteristics stand out. First, its foreign aid is closely tied to commercial interests and is outspokenly mutually beneficial - in contrast to much development assistance 
that is to be helping the recipient. Second, China follows a policy of non-interference in domestic affairs. This means China needs not exclude any countries from its aid programmes, and grants aid without prescribing democratic reforms or criticising human rights records. Third, under the flag of South-South cooperation Chinese foreign aid is attractive on the basis of China's own experiences in achieving economic development.

Joshua Cooper Ramo (2004) outlined a Chinese model of economic development - the Beijing Consensus - that as of late has experienced increasing international appeal. The Beijing Consensus, Ramo finds, is as much a model of economic development as of political governance that is characterised by a state-led development strategy, and strongly emphasising self-determination and respect for national sovereignty.

In those two areas, amongst other, the Beijing Consensus is distinguished from the Washington Consensus. The latter term was coined by John Williamson (1990) in describing a banker's favourite conditions when granting loans to Latin American countries, but quickly grew to define the West's approach to foreign aid. The Washington Consensus initially included conditionalities relating to minimising governmental intervention in the economy, privatising businesses, balancing budgets, and liberalising trade. In other words it prescribed that economic growth was to be achieved by securing a stable macroeconomic environment in which the free market forces would create wealth.

With the end of the Cold War, the political margin for manoeuvre increased. Accordingly the Washington Consensus evolved from focusing mainly on economic governance to a more positive and inclusive consensus in which good governance was the ultimate goal. For the World Bank, and other providers of foreign aid, good governance meant accountability, transparency, predictability and participation (Craig and Porter, 2006). Within this good governance paradigm, then, was intent of depoliticising governance through reforms.

This practice of conditionalities has later been criticised for being intrinsically unethical, being discriminately implemented, being ineffective and in some cases even outright harmful (Uvin, 2004). On these grounds, the disregard for the Washington Consensus by many developing countries has thus created a demand side for alternative policies. It is within this context that the Chinese foreign aid programme is rapidly expanding, as aid is provided without any reference to conditionalities of governance. As such, the attractiveness of the Chinese foreign aid is as much a rejection of the Washington Consensus - there are both pull and push effects.

\section{History of Chinese foreign aid}

The People's Republic of China is not a newcomer to foreign aid; it is re-emerging rather than emerging. African countries have been beneficiaries of Chinese foreign aid for over 50 years, over which course of time the Chinese relationship with Africa has evolved from ideological promotion, through phases of introvert focus and the use of foreign policy as a tool for economic policy.

\subsection{Ideological promotion}

The foundation for China's foreign aid programme lay in the 'Five Principles for Peaceful Coexistence', presented by then-Premier Zhou Enlai at the Bandung Conference in 1955. The principles underscored mutual benefits and national sovereignty, and were reaffirmed in Zhou's visit to Africa in the early 1960s. The visit symbolised the forging of closer ties between China and the African continent, and coincided with an acceleration of foreign aid contributions to Africa.

The levels of foreign aid were still small relative to the U.S. and Soviet Union, and China mostly supported anti-colonial movements (Burke et al., 2007). The major result of the Chinese foreign aid policy in Africa during this period of ideological promotion was not as much the economic impact for the African countries or a Marxist revolution - due to Cold War constraints. Rather it was a symbolic alignment of identities with African developing countries, in which developing countries assisted one another. The most tangible outcome of the foreign aid policy in this period was the diplomatic support for the One-China principle from African countries. In 1971 the People's Republic of China had enough support in the General Assembly of the United Nations (UN) to take over the permanent seat at the UN Security Council that the Republic of China (Taiwan) had held. The ideological spirit of the Five Principles continued to provide the basis for Sino-African engagement until 1976 (van de Looy and de Haan, 2006), when focus shifted inwards.

\subsection{Domestic pragmatism}

In the 1980s focus was shifted inwards for securing domestic economic growth amid major restructuring of the economy (van de Looy and de Haan, 2006). China's foreign policy also reflected the emphasis put on economic considerations. The attention granted to Africa suffered from the modernisation project, as the continent was seen as commercially irrelevant to China (Taylor, 1998). Still, while the foreign aid programme was considered subordinate to domestic economic restructuring, it was not discontinued. Though newly committed aid dropped 
significantly, the retreat from foreign aid to Africa was camouflaged by a continued rhetoric of South-South cooperation.

\subsection{Win-win cooperation}

The reforms initiated by Deng Xiaoping in 1978 meant that increasingly so, both politics and change were being driven by amassed knowledge rather than ideological considerations (Ramo, 2004). The 1980s witnessed two major shifts in how Chinese foreign aid was to be delivered - focussing more on win-win foreign aid, and being increasingly based on technical assistance and profit-seeking behaviour.

Firstly, while the Western donors were mostly occupied with advancing structural adjustment policies emphasising austerity and economic liberalisation, and failing to address the fiscal and balance of payments crises, China engaged in 'assisted sustainability' (Bräutigam, 2008a, 205). With China still being a developing country itself, and on its own a major recipient of development aid, the assisted sustainability programme was illustrative of a more practical approach to development in maintaining deteriorating state assets.

The second shift was the transition from a foreign aid policy grounded in ideology to being based on economics. After undertaking aid projects the Chinese companies had proved their technical expertise and quality of their work, in addition to having gained local knowhow and establishing connections with African decision-makers (Bräutigam, 2008a). As Deng's project of socialist modernisation dictated a focus on economic investments and a non-conflictual approach to international politics, Chinese companies then started competing for commercial contracts in Africa.

Still, through the 1980s Africa was seen as unimportant for the Chinese economic growth. China adopted a hard-line approach to African calls for increases in foreign aid, even publicly criticising African leaders (Taylor, 1998). Following China's negligence towards Africa, the 1989 Tiananmen Square incident revitalised the Sino-African relationship.

\subsection{Going-out strategy}

After having been lauded by the West for its successful economic development, China was heavily criticised for the violent crackdown on the demonstrations on the Tiananmen Square in 1989. The African countries' reactions were far more muted - some were even openly supportive. On this basis China and Africa again found room for revitalised political and economic engagement. Interests were aligned in both avoiding the promotion of human rights and democratisation, as well as the resentment of perceived Western neo-imperialist interference in domestic affairs. The link between international support for China and increased aid disbursements for Africa became the glue for the relationship, and developing countries became a cornerstone of Chinese foreign policy (Taylor, 1998). By 1990 China had become the single largest developing country aid donor, bar the OPEC members (Bräutigam, 2008a). Foreign aid was as a cheap means for securing international support after the Tiananmen.

The Soviet Union's fall and the end of the Cold War left somewhat of a power vacuum in Africa. The U.S. put less emphasis on containing communism in Africa, which meant that access to its foreign aid funds could be made conditional on governance reform. Thus the end of the Cold War also made U.S. foreign aid less attractive for African leaders. China was able to draw benefits from these new conditions in Africa.

The post-Tiananmen period saw Chinese officials returning to their foreign policy roots. A reaffirmation of Zhou's Five Principles, emphasising state sovereignty and non-interference, suited both Chinese leaders and African authoritarian regimes (Taylor, 1998). China's annual budget for foreign aid has further expanded from an annual figure of some $\$ 450$ million in 2000 to $\$ 1.4$ billion in 2007; Bräutigam (2008a) estimates African countries to receive some 44 per cent of this aid, amounting to $\$ 616$ million in 2007.

In addition to increased trading and foreign aid activities, China's national economic policy incorporated a strategy for internationalisation of its enterprises from 1992 onwards - the core element of 'going out' (Kragelund, 2008). By securing cheap access to finance, the policy would help enterprises to internationalise. 28 sectors were targeted for this special attention, and by 2006166 companies had been granted status of flagship enterprise (Corkin, 2007a). These companies also play a central role in China's African foreign aid policy, receiving commercial contracts part of the aid packages.

Nevertheless shifting motivation, the Chinese foreign aid programme in Africa has been continuous since its inception in the 1950s. The relationship has evolved beyond aid and is most notably institutionalised in the Forum on China-Africa Cooperation. In 2006, celebrating 50 years of diplomatic relations between China and African countries, the third high-level summit of the FOCAC was held in Beijing, and was unprecedentedly well attended by leaders from both sides. 


\subsection{The Forum on China-Africa Cooperation}

China is fast growing to become a more important trading partner for Africa, with two-way trade having surpassed the levels for the U.S. and French trade with Africa. Since the inception of FOCAC Sino-African two-way trade has grown from $\$ 10$ billion in 2000 (Alden, 2007), to topping more than $\$ 100$ billion in 2008 (DFID, 2009), making China Africa's most important trading partner.

Of the FOCAC meetings, the Beijing summit of 2006 has been the most significant. Dominated by the usual focus on high-level protocol and attention, the summit also presented a strong show of how seriously the Chinese take this new type of strategic partnership with Africa. In his opening address, President Hu Jintao announced eight steps China would take in strengthening the Sino-African relationship, including doubling its assistance within three years, providing preferential loans worth $\$ 3$ billion, creating the China-Africa Development Fund, as well as several billion dollars' worth of debt cancellation for highly indebted countries (Bräutigam, 2008b). Accordingly, Bräutigam (2008a) estimated Chinese development aid to Africa to reach $\$ 1$ billion in 2009. Still, this level of foreign aid, which arguably is comparable to ODA, puts China's development aid programme on par with those of Australia and Denmark.

In addition to the promises made, by China, the Beijing meeting had a highly symbolic effect; China and leaders of 48 African countries were standing on equal terms when dealing with each other. However, it also underscored the asymmetries of the Sino-African relationship while exemplifying the tri-levelled strategy of Chinese African engagement, as pointed out by Alden (2007). First, the lavish international attention paid to the summit presumably gave the African countries sought-after attention on the world stage. Secondly, the summit underscored the importance of Pan-Africanism and regionalism. Thirdly, all deals were negotiated on a bilateral basis. Accordingly, Guérin (2008) labelled the tri-levelled Chinese strategy of the FOCAC as false multilateralism. The importance of individual African leaders is highlighted, while the Chinese bargaining power maintained.

An understanding of the FOCAC as a tool for achieving economic policy goals is in line with the assertion that the political side of the relationship between China and Africa extends no further than the latter's support for the One-China principle, and joint calls for sovereignty and non-interference (Taylor, 1998). Foreign aid is actively being used to further these considerations, and the next section will outline how political considerations translate to aid disbursements.

\section{China's organisation of foreign aid}

Chinese foreign aid is mainly provided in the form of grants and technical assistance, concessional finance, and interest-free loans and debt relief (Burke et al., 2007). Aid is usually given on a project-basis as part of a larger package including commercial contracts (Alden, 2007). Organised in a purely state-to-state fashion, control over the project's tendering process in many cases lies with the Chinese government.

The political leadership, with the Chinese Communist Party's Leading Group and the State Council, provide the policy direction and budget allocation (IDRC, 2007). The Ministry of Commerce (MOFCOM) is mainly responsible for the foreign aid funds, underscoring the aid's commercial orientation, while a State Council subgroup, chaired by Premier Wen, makes the final decisions for all foreign aid projects (Davies, 2008). Upon approval MOFCOM initiates the tendering process, and the ministry is responsible for the day-to-day operations.

While the distribution of grants and technical assistance usually follows the process indicated above, the concessional lending is mainly organised around the China Exim Bank (Davies, 2008). Being a policy bank, Exim works with the government in realising political goals, rather than seeking private profits. This means that Exim seemingly is willing to operate at a loss.

First Exim Bank evaluates the foreign government's loan application, before, upon approval, the application is forwarded to MOFCOM, which negotiates a framework agreement with the borrowing country (Davies, 2008). Exim Bank then enters into a project loan agreement with the borrower, and usually requires that the loan-financed infrastructure contracts must be awarded Chinese contractors, and at least 50 per cent of project procurements should be provided by Chinese enterprises. After receiving invoices from a foreign executive agency, Exim Bank disburses funds directly to the Chinese contractors and exporters. Exim Bank then receives loan repayments, interest, fees and principal from borrowing government. The careful control China retains over the tendering process further indicates that also concessional loans are used to serve Chinese economic interests.

While other export credit agencies and international financial institutions are engaged on the African continent, China Exim Bank is distinguished mainly for its close alignment with the Chinese foreign aid policy of package deals in infrastructure development, and provided without conditions of political reform. As a policy bank, Exim 
helps enable Chinese enterprises to compete in the African market, usually on better financial terms relative to their competitors.

\subsection{Aid serving political and economic goals}

China usually prefers to combine loans and debt relief to mere grants, as the former involves a second-tier of Chinese influence in its relation with the recipient country. First China extends a loan, interest-free or concessional, before forgiving the debt - doubling the number of potential tie-in deals. It is estimated that as much as 90 per cent of interest-free loans are cancelled by China (Guérin, 2008), which would give China significant political leverage - or goodwill - with these countries.

The creation of the China Africa Development Fund (CADF) was announced at the Beijing summit. The \$5 billion fund is managed by the China Development Bank and its funds are made available only for Chinese companies and Sino-African joint ventures (Bräutigam, 2008b). The use of export and import credits is very similar to concessional finance and interest-free loans, with extension of credit to foreign importers and exporters of Chinese goods in order to increase trade (Davies, 2008). Chinese companies are major beneficiaries of both the $\mathrm{CADF}$ and Chinese trade credits, as their partaking is a requisite for fund disbursements.

\section{Chinese vs. traditional donors' foreign aid}

The Chinese foreign aid to Africa is different from the traditional foreign aid of the OECD-DAC in three important respects: the conditions under which aid is given; the mode of aid and linkages to commercial activities; and the overall relations between provider and beneficiary.

\subsection{Foreign aid with no strings attached}

The no strings attached-policy has led to especially negative criticisms of Chinese foreign aid, particularly due to its effect on democratic and administrative reform, as well as transparency and accountability of government. While traditional donors in many cases require reforms to be undertaken or elections to be held before aid is disbursed, China does not.

A good example of the effect of the no strings attached-policy is Chinese lending to the Democratic Republic of the Congo. In late 2007 it was announced that Chinese state-owned enterprises had been assigned contracts to build or refurbish railways, roads and mines at a cost of $\$ 12$ billion, in exchange for the rights to mine the same value of copper ore (The Economist, 2008). The loan was more than three times greater than the DRC's national budget, and about ten times the aid promised to the country by the consultative group of Western donors. The IMF and the donor-community, at unease with Chinese lending practices, were unwilling to extend further finance to the DRC unless the terms of payback were renegotiated to be of a more concessional nature (The Economist, 2009). In late August 2009 came news that the loan had indeed been renegotiated and downsized, following Western pressure.

On its part, in meeting this critique, China attempts to avoid scrutiny by asserting that transparency and accountability of government is a result of, not a prerequisite for, economic development. Such arguments should be acceptable also for African countries trying to avoid the exact same scrutiny. Some of the loans extended to Angola are also structured in an unusual manner that attracts additional criticism. For example China has provided a $\$ 9$ billion credit line that, instead of being controlled by Exim Bank, is directly controlled by the Angolan Government executive (Corkin, 2007b). This means that the parliament has little or no oversight over its use, and thus increases the possibility of graft and corruption against which China is unwilling to impose conditionalities.

The context for the no strings attached-policy can be traced back to Chinese domestic politics. As China is a communist state with an undemocratic government, it has a limited interest in promoting Western, democratic governance in the countries receiving its aid. Adhering to the principle of non-interference can also be seen as a method for ensuring China's own sovereignty, for which international support from the African countries is important ( $\mathrm{Li}, 2007)$.

\subsection{Sector preferences}

While traditional donors have avoided both the construction sector, due to corruption issues, and tying of aid, both are important in China's approach to Africa. Construction is possibly the sector in which China is most heavily engaged, with 43 per cent of foreign aid and investment going into infrastructure development in Africa (Lum et al., 2009). When foreign aid is given to African states, Chinese companies are always granted contracts for infrastructure developments, giving Chinese companies a good position from which they later can obtain commercial contracts. Another motivation seems to be an understanding that more infrastructure investment is 
needed in Africa. Drawing on their domestic experience, China benefited from technological diffusion of foreign direct investments in the construction sector (Corkin, 2007a). It would therefore not be unreasonable to assume that the Chinese expect a similar effect of technological diffusion in Africa.

China's sector preference is contrasted to that of the traditional donors, who tend to stress the importance of focussing on '[h]uman rights, gender equality, environment and other cross-cutting themes [that] strengthen empowerment, local capacity, participation, transparency, leadership and joint responsibility' (OECD, 2009, 13). China's approach may more easily answer the immediate, economic needs as perceived by many African leaders.

\subsection{Symmetry of relations}

There have been claims that China exploits its power as an increasingly important provider of foreign aid financing in order to gain concessions that are not favourable to the aid recipient. While the asymmetry in negotiating power in most cases favours China, at least two cases illustrate the point that African countries are not accepting Chinese aid in all situations. Rather it could be argued that the African countries may be driven just as much by a commercial focus and self-interest as is China.

The experience of national oil companies Sonangol of Angola, and Sinopec of China can illustrate this point. In 2006 the two companies agreed a $\$ 2.3$ billion contract for developing a refinery - 'a sum that shattered all previous records anywhere in the world,' wrote The New York Times (2006) at the time. However, this cooperation collapsed prior to project implementation, due to disagreements over the markets in which to sell the refined products. Burke et al. (2007) find this to exemplify that commercial interests are superior for both Angola and China. On the one hand, Chinese investors are risk averse investing only in projects they believe will be profitable, while on the other, Angola is guided by a stark focus on national sovereignty and ownership over strategically important resources.

China also benefits from contextualising its relationship with African countries as returning friend, rather than as a returning coloniser, as is the case with most of the other aid providers (with the exception of the U.S.). The shared history of anti-colonial struggles, it has been argued by e.g. Li (2007), means China more easily can build symmetric and friendly relations with Africa, compared to the former colonisers.

China is indeed more powerful than its individual African counterparts, and the structure of Sino-African relations favours the former, but the example above can be taken into account for a partnership of equals, in which both parties have the opportunity to withdraw if their expectations are not met. This implies that neither party is willing to cooperate on just any terms, and that the cooperation therefore might mutually beneficial, and is contrasted to the traditional view of developed countries helping developing countries on the terms of the former's choosing.

The next section will focus on how Chinese foreign aid policies are challenging the current paradigm of the Washington Consensus' good governance-orientation.

\section{China taking over?}

The Chinese foreign aid-challenge is substantial enough for other foreign aid actors to rethink their own strategies. This section discusses how these differences translate into changes on three fronts. The strict donor-recipient conceptualisation is challenged by a focus on partnership of equals. The no strings attached nature of Chinese foreign aid undermines the Western donors' leverage for inducing good governance reform in recipient countries - the very core of the Washington Consensus. China's independent foreign aid policy adds to the strain of the multilateral organisations, for example with respect to debt relief coordination.

\subsection{Conceptualisation}

Africa may be credited with increased attention from donors of foreign aid. Over the past few years Europe has sought to re-launch its ties with African leaders. In a measure directly influenced by the attention Chinas is paying Africa, the Portuguese EU presidency in 2007 arranged a high-level EU-Africa summit that was attended by EU and African leaders alike. The Joint EU-Africa Strategy adopted at the summit revolutionised the manner in which to conceptualise the EU-Africa relationship.

The summit aimed to move past the colonial history. Both the EU and Africa, operating on equal terms, were 'resolved to build a new strategic political partnership for the future, overcoming the traditional donor-recipient relationship' (EU, 2007b, 2). This stressing of renewing a strategic partnership among equals echoes the Chinese approach, thus it can be seen as the EU courting African leaders who face alternative providers - or partners - in foreign aid provision.

The Joint Strategy noted that the EU-Africa relationship should build on a stronger bilateral 
development-oriented trading relationship (EU, 2007a). This may possibly signify a shift from aid to trade, an appreciation of commercial incentives, as well as a decreasing importance ascribed to multilateral developmental organisations.

The U.S. has also granted Africa increased attention of late; both President Barack Obama and Secretary of State Hillary Clinton visited the continent within their first seven months in office. While maintaining that Western aid is dependent upon good governance, it is reported that, despite her being urged to do so by prominent dissidents, Secretary Clinton chose not to take a stance against corruption and power abuse in Angola, as she had done in both Kenya and Nigeria (Financial Times, 2009). This is mainly seen as an attempt at easing the access to Angolan petroleum resources, and might indicate a willingness, in the face of Chinese competition, to relinquish certain aspects of aid conditionalities in exchange for strategic resources. As the U.S. backtracks on its liberal standards, Holslag (2009) finds it is increasingly flirting with the Beijing Consensus. This means that national interests, not universal norms, are increasingly becoming the drivers for international cooperation.

\subsection{Conditionalities}

By merely providing alternative sources of financing for developing countries, China is effectively undermining the traditional donors' potential for imposing conditionalities of recipient reform (Woods, 2008). While it could be argued that this competition is either enabling developing countries for self-determination, or enabling them to play donors off against one another, this article deals with the changes themselves and not their normative implications.

One example is the breakdown of negotiations between the IMF and Angola in 2006. As Angola sought aid financing, the traditional donors would not hold a donors' conference until Angola had presented a Poverty Reduction Strategy Paper and made a deal pertaining to corruption and economic management with the IMF (Taylor, 2006). Angola then turned its back on the IMF as China were willing to provide a concessional loan tied only to a deal on future oil supplies. This type of Chinese unilateral lending clearly limits the traditional donors' leverage with the aid recipients.

Traditional donors' aid policies indicate that the policy of conditionalities is subject to change. During the 2007 EU-Africa summit the former seemed willing to yield ground on its earlier steadfastness on good governance promotion. First, the Portuguese EU Presidency were so eager to present the EU on equal terms with the African leaders that it invited Sudanese President Omar al-Bashir and Zimbabwean President Robert Mugabe - even when the presence of the latter meant that British Prime Minister Gordon Brown would refuse to attend (The Economist, 2007). Granting such diplomatic attention to arguably two of Africa's foremost human rights abusers can hardly be seen as anything but the EU retracting on the principles of good governance in its relationship with Africa.

Secondly, the EU appeared less critical of African regimes' approach to human rights, transparency and democratic values. While the joint strategy indeed stressed the importance of these issues, the Portuguese minister responsible for the summit said that the European insistence on governmental reform in Africa had been 'excessively simplistic', and that focus should be on the essence of government rather the particular form of decision-making (The Economist, 2007).

The EU also seems less inclined to use conditionalities on aid provision in support of the principles of good governance. The joint strategy said that the EU should move towards result-oriented aid, while limiting the use of conditionalities (EU, 2007a). The increasing aid competition can be identified in the EU's more pragmatic approach towards the African continent.

While the extent of Chinese crowding out of traditional donors should not be exaggerated - China is neither willing nor able to be a last line provider of foreign aid for all African developing countries - the potential for these countries to attain Chinese financing induces traditional lenders to provide foreign aid that the recipients find attractive. Traditional donors now face the threat that expensive negotiations result in nothing, as well as they may find that inducing some elements of good governance reform is preferable to no reform.

\subsection{Multilateralism}

The lack of concerted action among emerging and traditional donors is also expected to have an effect on the already strained multilateral aid organisations (Woods, 2008). The organisations experiences difficulties designing policies on which all members can agree, sometimes resulting in a policy of the lowest common denominator. Consequently, the member states in many cases prefer to invest in their own, parallel foreign aid agencies. Additionally, when using the multilateral institutions, such as the World Bank, the donors often include their own demands, funds and procedures that bypass the agreed upon mechanisms (Woods, 2008). When 
multilateral aid is used in this manner it is significantly undermining the multilateral aspect.

The Chinese unilateral foreign aid policy, with its commercially oriented nature, may add to the stagnant role of the multilateral institutions. As Chinese foreign aid is a tool for commercial interests, there is reason to believe that traditional donors also will be more likely to use it in a similar fashion - in which case the multilateral institutions will be further down-prioritized. More than two-thirds of DAC members' ODA is provided bilaterally (OECD, 2009), and the role of multilateral foreign aid faces the threat of increasing marginalisation as foreign aid becomes more politicised.

\subsection{Debt relief}

There is growing concern that the build-up of Chinese debt in Africa is unsustainable, and may result in a debt crisis similar to that of the 1980s. China's independent lending policy also threatens further multilateral debt-relief actions.

Traditional donors are expected to be less willing to engage in debt relief programmes when there is no concerted action, that is, when emerging donors are possible free-riders and cancelled debt quickly is replaced by new debt (Woods, 2008). Manning (2006) identifies a challenge for debt sustainability in that the former highly indebted countries, for the first time since 1982, effectively have the freedom of action to ignore fiscal prudence.

\subsection{A sustainable challenge?}

The question of how China can maintain its policy of non-interference and at the same time integrating into the world order is important for assessing the durability of the Chinese challenge. Chinese policy formation does not take place in a vacuum, but is receptive to international pressures. This was illustrated by the manner in which the criticism of China's relationship with Sudan was translated into policy change in the period prior to the 2008 Beijing Olympic Games.

China is still operating outside the global foreign aid regime. However, Bräutigam (2008a) has found some indications that the way China organises its system reflects the norms established by the OECD. Lancaster (2007) notes that China has developed a dialogue with the British Department for International Development, while China and the World Bank recently agreed to jointly develop aid projects in Africa, shortly after China made its debut on the list of donors to the World Bank's International Development Association (Reuters, 2007). It is also reported that Chinese diplomats attend the meetings where Western donors coordinate their development schemes (The Economist, 2009). However such collaboration is a relatively recent development in China's African engagement, and Corkin (2007b) finds that cooperation takes place only on smaller-scale projects. China prefers to 'go it alone' on the big loans that usually involve commercial contracts for Chinese enterprises.

The U.S. attempts to have China embrace the good governance-mode of foreign aid. Thomas Christensen, then-U.S. Deputy Assistant Secretary of State, was hopeful that China, as it invests more in Africa, will come to the conclusion that conditionalities concerning good governance are a good thing for both investors and for the countries that receive the aid (Christensen, 2008). However there is a long way from dialogue to action. Even as the U.S. attempts to have China reconsider its non-interference policy, Christensen admits that there is no evidence that China has changed the no strings attached policy. China's interests lie in balancing its advantage of providing attractive foreign aid with its reputation with the traditional donors.

Questions are being raised as to whether China indeed seeks a form for economic cooperation with African countries, or whether it really seeks to establish itself as a major international power on the African continent. As Campbell $(2009,75)$ argues, "[b]ehind the language of friendship and co-operation lay an understanding of the vast treasures of Africa and the major genetic, mineral and energy resources that are coveted in this century of converging technologies." In this view, China's commercially orientated African engagements are merely one part of a multidimensional power projection in which international political, economic and military influence are the sought-after objectives.

Liu Guijin, the Special Representative of the Chinese Government for African Affairs, emphasises that China seeks to cooperate with Western countries in 'the spirit of equality and with a respect for Africa' (quoted in Beijing Review, 2008, 9). However, the emphasis on equality and respect indicates a Chinese unwillingness to give ground on non-conditionality and non-interference. Furthermore, in a speech at the United Nations in late 2008, Premier Wen stressed both the continuance of China's independent foreign policy, and that equality and mutual benefit, rather than ideology or political system, would be the basis for Chinese international cooperation (Wen, 2008). These are indications that China's assertiveness is growing with its international influence. It would therefore be premature to assume that China will substantively change their successful foreign aid strategy over the foreseeable future. 


\section{Concluding remarks}

This article has argued that China is challenging the traditional donors in providing the frame of reference for foreign aid. Foreign aid is increasingly becoming an outspoken tool for achieving the national interest.

Compared to traditional donors China has several advantages in its foreign aid programme. China has provided foreign aid to Africa continuously for over 50 years, and is consequently seen as a reliable and long-term partner. The alignment of identities between China and Africa - developing countries with colonial pasts - reinforces the pattern of South-South cooperation. This challenges the traditional donors to adopt a new approach of equal parts towards African countries.

China's foreign aid further challenges the traditional donors' imposition of conditionalities on aid provision. The latter's room for manoeuvre is reduced by the existence of alternative providers, and there is evidence that traditional donors are retracting on their use of conditionalities.

The type of aid provided is challenged by China's insistence that foreign aid must be mutually beneficial. This entails that China is able to focus its effort on aid projects that create substantial revenues to Chinese enterprises. For example is much of the Chinese foreign aid targeted towards increasing trade between China and Africa. Commercial considerations assume a prominent standing in Chinese foreign aid policies, illustrated by the fact that the Ministry of Commerce or the China Exim Bank retain the aid projects' tendering processes.

Multilateralism is also challenged. As China is pursuing an independent policy of foreign aid lending, it presents a challenge for multilateral debt relief initiatives, in fear of increased build-ups of debts owed to China. Multilateral institutions such as the World Bank stand the risk of decreasing influence. For example the World Bank has been outcompeted by China in instances of development country financing, further adding to a trend of increased focus on bilateral foreign aid initiatives.

The challenges posed by the Chinese foreign aid engagement are further intensified by the other emerging donors of foreign aid, all providing aid on terms of their own choosing. While there are differences in the policies of the emerging donors, it is the similarities that may well add to define the new paradigm of foreign aid. The emerging donors provide foreign aid on different terms, in different sectors, through different organisational structures, and with different goals than do the traditional donors.

China is gradually taking over in providing the frame of reference for foreign aid.

\section{References}

Alden, C. (2007). China in Africa. London: Zed Books.

Beijing Review. (2008). China-Africa Seeking Equality. Beijing Review, 51(41), 8-9.

Bräutigam, D. (2008a). China's Foreign Aid in Africa: What Do We Know?, in R. I. Rothberg (Ed.) China Into Africa: Trade, Aid, and Influence. Washington, D.C.: Brookings Institution Press. pp 197-216.

Bräutigam, D. (2008b). China's African Aid: Transatlantic Challenge. Washington, D.C.: The German Marshall Fund of the United States.

Burke, C., Corkin, L. \& Tay, N. (2007). China's Engagement of Africa: Preliminary Scoping of African Case Studies. Angola, Ethiopia, Gabon, Uganda, South Africa, Zambia. Centre for Chinese Studies, University of Stellenbosch.

Campbell, H. (2009). China in Africa: Challenging US global hegemony. Third World Quarterly, 29, 89-105.

Christensen, T. J. (2008). Oral Testimony before the U.S. Senate Committee on Foreign Relations Subcommittee on African Affairs 4 June, 2008. [Online] Available: http://foreign.senate.gov/archives/2008/archive060408.ram (June 17, 2009).

Corkin, L. (2007a). The Strategic Entry of China's Emerging Multinationals into Africa. China Report, 43, 309-22.

Corkin, L. (2007b). China's Contribution to the Development of African Infrastructure through Investment in the Extractive Industries. African Forum and Network on Debt and Development, AFRODAD Occasional Papers, No. 8.

Craig, D. \& Porter, D. (2006). Development beyond Neoliberalism? Governance, Poverty Reduction, and Political Economy. London: Routledge.

Davies, M. (2008). How China Delivers Development Assistance to Africa. Centre for Chinese Studies, University of Stellenbosch. 
DFID. (2009). China Africa Two-Way Trade - Recent Developments, UK Department for International Development. [Online] Available: www.dfid.gov.uk/documents/publications/china-africa-trade.pdf (June 17, 2009).

EU. (2007a). The Africa-EU Strategic Partnership: A Joint Africa-EU Strategy, 16344/07 Presse 291 December 9 2007, Brussels: Council of the European Union.

EU. (2007b). Lisbon Declaration - EU Africa Summit (Lisbon, 8-9 December, 2007), Presse $29016343 / 07$ December 9 2007. Brussels: Council of the European Union.

Financial Times. (2009). Clinton's Oily Policy. Financial Times August 17.

Guérin, É. (2008). Chinese Assistance to Africa: Characterization and Position Regarding the Global Governance of Development Aid. Paris: Institut du Développement Durable et des Relations Internationales, Idées Pour Le Débat, No 03/2008.

Holslag, J. (2007). Friendly Giant. China's Evolving Africa Policy. Brussels: Brussels Institute Of Contemporary China Studies, Asia Paper.

Holslag, J. (2009). The Rise of the Beijing Consensus, Project Syndicate. [Online] Available: http://www.project-syndicate.org/commentary/holslag1 (June 17, 2009).

IDRC. (2007). Emerging Donors in International Development Assistance: The China Case. Ottawa: International Development Research Centre, Partnership \& Business Development Division.

Kragelund, P. (2008). Knocking on a Wide Open Door: Chinese Investment in Africa. Oxford: University of Oxford, Paper Prepared for the Mine Watch Zambia Conference: Politics, Economy, Ecology and Investments in Zambia, 19 - 20 September 2008.

Lancaster, C. (2007). The Chinese Aid System, Center for Global Development. [Online] Available: http://www.cgdev.org/files/13953_file_Chinese_aid.pdf(17 January, 2010).

Li, A. (2007). China and Africa: Policy and Challenges. China Security, 3, 69-93.

Lum, T., Fischer, H., Gomez-Granger, J. \& Leland, A. (2009). China's Aid Activities in Africa, Latin America, and Southeast Asia. Washington, D.C.: Congressional Research Service, R40361.

Manning, R. (2006). Will 'Emerging Donors' Change the Face of International Co-Operation? Development Policy Review, 24, 371-85.

OECD-DAC. (2009). Better Aid: Managing Aid: Practices of DAC Member Countries. Paris: Organisation for Economic Co-Operation and Development - Development Assistance Committee.

Ramo, J. C. (2004). The Beijing Consensus. London: The Foreign Policy Centre.

Taylor, I. (1998). China's Foreign Policy towards Africa in the 1990s. The Journal of Modern African Studies, 36, 443-60.

Taylor, I. (2006). China's Oil Diplomacy in Africa. International Affairs, 82, 937-59.

The Economist. (2007). A desperate suitor. The Economist, print edition, December 6.

The Economist. (2008). Special Report: China's quest for resources. The Economist, print edition, March 13.

The Economist. (2009). An (iron) fistful of help. The Economist, print edition, May 4.

The New York Times. (2006). China's African Adventure. The New York Times, November 19.

Uvin, P. (2004). Human Rights and Development. Bloomfield Conn.: Kumarian Press.

van de Looy, J. \& de Haan, L. (2006). Africa and China: A Strategic Partnership? Strategic Analysis, 30, $562-75$.

Wen J. (2008). A China Committed to Reform and Opening-Up and Peaceful Development, Statement at the General Debate af the 63rd Session of the UN General Assembly, New York: United Nations. [Online] Available: http://www.bjreview.com.cn/document/txt/2008-12/03/content_168043.htm (December 12, 2009).

Williamson, J. (1990). What Washington Means by Policy Reform, in J. Williamson (Ed.) Latin American Adjustment: How Much Has Happened? Washington D.C.: Institute for International Economics.

Woods, N. (2008). Whose Aid? Whose Influence? China, Emerging Donors and the Silent Revolution in Development Assistance. International Affairs, 84, 1205-21. 
Abbreviations:

CADF

China Africa Development Fund

DRC

Democratic Republic of the Congo

Exim Bank

The Export-Import Bank of China

$\mathrm{EU}$

European Union

FOCAC

Forum on China-Africa Cooperation

IMF

International Monetary Fund

MDB

Multilateral Development Bank

MOFCOM

ODA

Ministry of Commerce of the People's Republic of China

OECD

Official Development Aid

OECD-DAC

Organisation for Economic Cooperation and Development

Sinopec

OECD Development Assistance Committee

UN

China Petroleum \& Chemical Corporation

U.S.

United Nations

United States 